\title{
Comprehensive analysis of sustainable development of the countries of the Eurasian Economic Union
}

\author{
Tamara Selishcheva ${ }^{1, *}$, Sergey Dyatlov ${ }^{1}$, Natalia Sopina ${ }^{1}$, Olga Ilyina $^{2}$ and Victor Trunin ${ }^{3}$
}

${ }^{1}$ St. Petersburg State University of Economics, Faculty of Economics and Finance, 191023 Sadovaya St., 21, St. Petersburg, Russia

${ }^{2}$ St.Petersburg State University of Economics, Faculty of Informatics and Applied Mathematics, 191023 Sadovaya St., 21, St. Petersburg, Russia

${ }^{3}$ The Russian Presidential Academy of National Economy and Public Administration, Faculty of Economics and Finance, 199178, Sredny prospect V.O., 57/43, St. Petersburg, Russia

\begin{abstract}
Research background: the economies of the member states of the Eurasian Economic Union are of a raw material nature, therefore they have a large carbon footprint in their products and serious environmental problems. This complicates the transition to sustainable development, which presupposes the coordinated development of the economy, ecology and social sphere.

Purpose of the article: based on the analysis of the system of indicators of the effectiveness of sustainable development, identify the existing problems of the EAEU countries and propose a system of measures to resolve them.

Methods: the study analyzed the literature on sustainable development, studied and analyzed strategies for the transition to sustainable development of the EAEU countries, used statistical analytical reports and forecasts of the main indicators of sustainable development presented on the websites of the UN, the Eurasian Economic Commission, the World Data Atlas "Knoema", Yale Center for Environmental Law and Policy, Boston Consulting Group.

Findings: An assessment of the indicators of the sustainability of development of the EAEU member states was carried out, an analysis of their policies within the framework of the Paris Agreement was given. The conclusion is made about the decrease in the efficiency of the rational use of ecosystems and natural resources in the EAEU countries, the growth of environmental problems. This hinders the progress of the EAEU countries along the path of sustainable development. The need for the formation of a unified supranational environmental legislation within the EAEU has been proved.
\end{abstract}

Key words: Eurasian Economic Union; sustainable development; environmental cooperation; environmental efficiency.

JEL Classification: $F 15 ; F 18 ; Q 51$

\footnotetext{
* Corresponding author: selishcheva@list.ru
} 


\section{Introduction}

The Eurasian Economic Union (EAEU), as a regional integration organization, began functioning in 2015 and includes 5 countries: Armenia, Belarus, Kazakhstan, Kyrgyzstan and the Russian Federation. After the collapse of the Soviet Union, the existing environmental problems in each of the former Soviet republics, including the member countries of the Eurasian Economic Union, remained and even worsened due to the crisis state of the economies and the lack of funds to finance environmental protection. The consequences of the exploitation of the natural resources of one country can have a negative impact on other countries. The ecological and administrative boundaries of the EAEU member states do not coincide. The Treaty "On the Eurasian Economic Union" (2014) does not contain a provision on environmental protection. Environmental relations between the EAEU member states are governed by the Agreement on Interaction in the Sphere of Ecology and Environmental Protection of the CIS member states (2013). The Interstate Ecological Council of the CIS member states functions. There are bilateral treaties between the EAEU member states and foreign countries, but a unified legal framework has not yet been created to regulate environmental relations in the Union.

The EAEU countries have resource-oriented export-oriented economies, so there is an increased anthropogenic load on the environment. That is why it is very important to study environmental problems and environmental protection issues during the integration of the Union member states. The ultimate goal of regional integration is to improve the quality of life of the population of the integrating countries, which is closely related to the environmental factor. The sustainability of the ecological system is closely related to economic security and the political well-being of the state. Very often, when the economic interests of individual states are achieved, environmental disputes arise. This also applies to the countries of the Eurasian Economic Union, especially in terms of shared natural resources. The world is undergoing a process of "greening" international economic relations. The EAEU member states are faced with the task of creating normative documents that would allow unifying environmental legislation within the Union, as well as, along with economic, effective environmental integration. The purpose of the article is to investigate the existing problems of sustainable development of the EAEU countries and, on this basis, propose measures to solve them.

\section{Materials and methods}

The problems of the deteriorating situation with the environment in the course of the growth of the world economy forced scientists in the last century to study this phenomenon, and the theory of sustainable economic development appeared and began to develop in Western economic science. Its formation is directly related to the work of foreign scientists: Meadows et al. (2014); Nordhaus (2018), Tol (2019) and a number of other scientists. Problems of sustainable are being investigated by Russian economists Burmatova (2021), Ilyin and Ursul (2019), Porfiryev et al. (2020), Ursul et al. (2018), Yakovlev et al. (2020) and other scientists develop problems of sustainable development in their scientific works.

Scientists are developing various models for the transition to sustainable development: green economy and green growth economy, bioeconomy, circular economy, blue economy and others. So, the models of the "green" economy are studied by German economist Fux, R. (2016); Russian scientists Bobylev, S.N. (2020), Borkova, E. et al. (2020), DanilovDanil'yan et al. (2020), Nesterenko et al. (2020), Porfiriev (2019), Semyachkov et al. (2021), Yakovlev et al. (2020) and other scientists.

For the countries of the Eurasian Economic Union, environmental problems and climate change in the course of economic activity are of paramount importance, since they have an economic structure with a predominance of the raw materials sector. At the same time, the EAEU Treaty does not contain a section on environmental interaction; the problem of economic integration is highlighted. Although recently in the EAEU, more and more attention is paid to climatic changes, which are occurring in Russia and Kazakhstan much faster than on the planet as a whole. The countries of the Union are facing an acute problem of ecological integration. The issues of sustainable development of the EAEU member states and the problems of their ecological integration are studied by Russian economists: Abramov (2020), Dyatlov et al. (2020), Gibadullin (2019), Glazyev et al. (2018), Greenberg (2021), Ryazantsev et al. (2021), Selishcheva et al. (2019) and others. At the same time, the severity of the problems of sustainable development in the EAEU requires a broader and more thorough study by economists, ecologists, practitioners, representatives of the member states in order to determine the main ways to solve these problems.

The research used evolutionary and systemic approaches, methods: comparative analysis of statistical data, formal logic; the principle of the unity of the historical and the logical.

\section{Results and discussion}

Currently, the EAEU member states are faced with the task of creating regulatory documents that would allow unifying environmental legislation within the Union.

The EAEU member states adopted the concepts of transition to sustainable development: in Armenia, in 2008, the country's government approved the "Sustainable Development Program"; in Belarus in 1997, the National Strategy for Sustainable Socio-Economic Development of the Republic of Belarus was developed (a new version is developed once 
every 5 years for the next 15 years); in Kazakhstan - Decree of the President of the Republic of Kazakhstan dated November 14, 2006 No. 216 "Concept of the transition of the Republic of Kazakhstan to sustainable development for 2007 - 2024" (new edition of 2011); Kyrgyzstan in 1997 adopted the "Concept of Sustainable Human Development"); in Russia - Decree of the President of the Russian Federation of April 1, 1996 No. 440 "On the Concept of the Transition of the Russian Federation to Sustainable Development". The countries of the Union adopted strategies for the transition to a green economy, ratified the 2015 Paris Agreement (Yakovlev et al., 2020).

It is necessary to take into account the environmental interests of each state when developing legislation in the economic sphere, since many natural resources belong to the resources shared by the Eurasian countries. International regulation of economic activity, which affects the shared natural resources of the EAEU member states, can only be effective if a multilateral agreement between the countries is concluded, which should be based on the concept of sustainable development (Abramov et al., 2020).

Deepening integration between the EAEU member states can have a great impact on improving the environmental situation in the countries (Selishcheva et al., 2019).

The environmental sustainability of the development of the Union countries can be analyzed using a number of international indicators, one of which is the Environmental Performance Index, (EPI) (see table 1).

Table 1. Rating of the EAEU member countries and a number of countries in the world according to The Environmental Performance Index, EPI,

2010-2020 (in points: from "0" to "100")

\begin{tabular}{|c|c|c|c|c|c|}
\hline \multirow[t]{2}{*}{ Country } & \multicolumn{2}{|l|}{2010} & \multicolumn{2}{|l|}{2020} & \multirow{3}{*}{$\begin{array}{l}\text { Rank change } \\
2020 / 2010\end{array}$} \\
\hline & Rating & Index & Rating & Index & \\
\hline Number of countries & \multicolumn{2}{|l|}{163} & \multicolumn{2}{|l|}{180} & \\
\hline \multicolumn{6}{|c|}{ Countries leading the EPI index } \\
\hline Danmark & 32 & 69,2 & 1 & 82,5 & +31 \\
\hline Luxembourg & 41 & 67,8 & 2 & 82,3 & +39 \\
\hline Switzerland & 2 & 89,1 & 3 & 81,5 & -1 \\
\hline Great Britain & 14 & 74,2 & 4 & 81,3 & +10 \\
\hline France & 7 & 78,2 & 5 & 80 & +2 \\
\hline \multicolumn{6}{|l|}{ USA and China } \\
\hline USA & 61 & 63,5 & 24 & 69,3 & +38 \\
\hline China & 121 & 49,0 & 120 & 37,3 & +1 \\
\hline \multicolumn{6}{|c|}{ EAEU member countries } \\
\hline Armenia & 76 & 60,4 & 53 & 52,3 & +23 \\
\hline Belarus & 53 & 65,4 & 49 & 53 & +4 \\
\hline Kazakhstan & 92 & 57,3 & 85 & 44,7 & +7 \\
\hline Kyrgyzstan & 79 & 59,7 & 105 & 39,8 & -26 \\
\hline Russia & 69 & 61,2 & 58 & 50,5 & +11 \\
\hline
\end{tabular}

Source: Yale Center for Environmental Law and Policy

The Environmental Performance Index (EPI), developed by the Center for Environmental Policy and Law at Yale University, ranks countries in the world by their environmental performance and allows you to quantify them. The EPI index is calculated according to 16 indicators, which are combined into two environmental groups: 1) reduction of the environmental impact on human health; 2) ensuring the reasonable use of ecosystems and natural resources.

As you can see from the table. 1, the first 5 places out of 180 in 2020 were occupied by Denmark, Luxembourg, Switzerland, the United Kingdom and France. At the same time, in absolute terms, the EPI index and ratings for all the listed countries, with the exception of Switzerland, increased. This indicates an improvement in the ecological situation in them. Switzerland has moved from 2nd to 3rd place in 10 years, but has a high EPI (81.5 points).

Over the past 10 years, the United States has improved its EPI rating by 38 positions: from 61 st to 24 th place, and the EPI itself has grown in absolute value from 63.5 to 69.3 points, which is a sign of environmental improvement.

Over the past decade, China has risen one position in the ranking from 121 to 120, but the EPI itself has dropped from 49.0 to 37.3 points, which allows us to conclude that an unfavorable trend in the ecology of this country, which also worsens the ecology of transboundary states. including the EAEU member states (Borkova et al, 2020).

From 2010 to 2020 for four countries of the Union, ratings on the EPI index rose: Armenia by 23 positions, Belarus by 4 , Kazakhstan by 7, and Russia by 11 positions, but the absolute value of the index for these countries dropped (see Table 1). Over the past 10 years, Kyrgyzstan has dropped by 26 positions in the EPI rating: from 79 th to 105 th place, and the index itself has decreased by almost 20 points. This indicates a deterioration in the environmental situation, in particular, an increase in the burden on the environment, a decrease in the efficiency of the rational use of ecosystems and natural resources in the Eurasian Economic Union (Dyatlov and Selishcheva, 2020). 
You can also assess the environmental aspect of sustainable development of the EAEU member states using the Sustainable Economic Development Assessment (SEDA), which is calculated by the Boston Consulting Group (BCG) annually for 152 countries.

The SEDA Index is calculated on the basis of 10 indicators, which are grouped into 3 categories:

- economy: indicators of income, economic stability and employment;

_ investments: investments in education, health care and infrastructure;

- $\quad$ sustainable development: the environment and 3 factors that promote social inclusion: equality, strong civil society and good governance.

The SEDA index is assessed as a whole in points from " 0 " to " 100 " for each of the 10 indicators separately. Table 2 shows the ranking of the world countries according to the SEDA index, where we are interested in its dynamics from 2010 to 2020 and such an important indicator as "environment".

Table 2. Rating of the EAEU member states and a number of countries in the world according to the Sustainable Economic Development Assessment (SEDA) index, 2010-2020 (in points: from "0" to "100")

\begin{tabular}{|c|c|c|c|c|c|c|c|}
\hline \multirow[t]{2}{*}{ Countries } & \multicolumn{3}{|l|}{2010} & \multicolumn{3}{|l|}{2020} & \multirow{2}{*}{$\begin{array}{l}\text { Rank } \\
\text { change } \\
\text { SEDA } \\
2020 / 2010\end{array}$} \\
\hline & Rating & SEDA & $\begin{array}{l}\text { Environme } \\
\text { nt }\end{array}$ & Rating & SEDA & Environment & \\
\hline \multicolumn{8}{|c|}{ Countries leading the SEDA index } \\
\hline Switzerland & 2 & 85,7 & 56,6 & 1 & 87,0 & 62,1 & +1 \\
\hline Norway & 1 & 88,1 & 59,5 & 2 & 86,5 & 61,1 & -1 \\
\hline Finland & 3 & 84,8 & 69,3 & 3 & 84,2 & 73,2 & 0 \\
\hline Iceland & 5 & 84,2 & 81,1 & 4 & 84,2 & 79,1 & +1 \\
\hline Austria & 9 & 81,2 & 58,2 & 5 & 83,9 & 64,5 & +4 \\
\hline \multicolumn{8}{|c|}{ USA and China } \\
\hline USA & 17 & 74,8 & 53,6 & 16 & 76,9 & 57,0 & +1 \\
\hline China & 76 & 46,3 & 8,6 & 58 & 52,7 & 13,6 & +18 \\
\hline \multicolumn{8}{|c|}{ EAEU member countries } \\
\hline Armenia & 64 & 49,9 & 54,1 & 59 & 52,6 & 38,6 & +5 \\
\hline Belarus & 48 & 56,6 & 46,5 & 47 & 58,4 & 33,1 & +1 \\
\hline Kazakhstan & 54 & 53,8 & 35,8 & 54 & 56,1 & 9,9 & 0 \\
\hline Kyrgyzstan & 91 & 41,8 & 45,6 & 85 & 42,5 & 15,6 & +6 \\
\hline Russia & 57 & 53,0 & 49,8 & 53 & 56,4 & 31,6 & +4 \\
\hline
\end{tabular}

Source: Boston Consulting Group

As it can be seen from Table 2, the leading countries in 2020 in terms of the economic development sustainability index were: Switzerland, Norway, Finland, Iceland, Austria. At the same time, it can be noted that from 2010 to 2020. these countries had the highest SEDA scores with little change. At the same time, one of the 10 composite indicators of the index of sustainable economic development - "environment" - for 2010-2020. for all five leading countries increased, which indicates an improvement in the environmental situation in these leading countries.

USA from 2010 to 2020 from the 17th place in the rating has risen to the 16 th, their "environment" indicator has improved (increased from 16 to 57).

As for China, as a cross-border state of the EAEU member states, in 2010 it took the 76th place, and in 2020 - the 58th place, but at the same time, China has a very small contribution to the SEDA index of the "environment "- 13.6 points (for comparison, Switzerland has 62.1 points), which indicates great environmental problems in this country, which undoubtedly affect the environmental situation in the transboundary regions of the EAEU member states (Semyachkov, 2021).

The countries of the Eurasian Economic Union have increased their positions in the ranking of the index of sustainable economic development from 2010 to 2020 , the absolute values of the SEDA index have also increased. At the same time, the points for such an indicator of the SEDA index as "environment" for all EAEU countries for 2010-2020 decreased significantly, especially sharply in Kazakhstan (from 35.8 to 9.9 points) and Kyrgyzstan (from 45.6 to 15.6 points) (see Table 2). This indicates the growing environmental problems in the Union countries (Gibadullin et al, 2020).

The ecological aspect of sustainable development of the EAEU member states can be analyzed by the indicator "Sustainable Development Goals Index" (SDG Index), which were adopted in 2015 (17 goals) by the UN member states within the framework of the "Agenda in areas of sustainable development until 2030". This index has been calculated since 2016 by the UN and the German Bertelsmann Stiftung. Of the 17 sustainable development goals, five goals are related to the preservation of the existing ecosystem: goal number 6 - "Clean water and sanitation", goal number 7 "Affordable and clean energy", goal number 13 - "Combating climate change", goal number 14 - Conservation of Marine Ecosystems, Goal 15 - Conservation of Terrestrial Ecosystems. 
The level of implementation of the goals of sustainable development is carried out at the national, regional (regions of the world) and global levels. Table 3 shows the rating of the Progress Index for the Sustainable Development Goals of the EAEU Member States.

Table 3. Sustainable Development Goals Index, SDG Index EAEU of member states in 2016-2020

\begin{tabular}{|l|l|l|l|l|l|l|}
\hline \multirow{2}{*}{ Country } & \multicolumn{7}{|l|}{ Country place in the ranking by SDG Index } & Change \\
\cline { 2 - 6 } & 2016 & 2017 & 2018 & 2019 & 2020 & $2020 / 2016$ \\
\hline Armenia & 50 & 43 & 58 & 75 & 58 & -8 \\
\hline Belarus & 23 & 21 & 23 & 23 & 24 & -1 \\
\hline Kazakhstan & 54 & 46 & 65 & 77 & 59 & -5 \\
\hline Kyrgyzstan & 67 & 49 & 51 & 48 & 44 & +23 \\
\hline Russia & 47 & 62 & 63 & 55 & 46 & +1 \\
\hline
\end{tabular}

Source: UN data

As it can be seen from the data in Table 4, in 2020, among the EAEU member states, Belarus took the first place in the implementation of the SDGs (24th place), the second - Kyrgyzstan (44th place), the third - Russia (46th place), the fourth - Armenia (58th place) and fifth - Kazakhstan (59th place). Moreover, from 2016 to 2020 in a number of EAEU countries, the rating on the SDG Progress Index has deteriorated: in Armenia by 8 positions, in Belarus - by 1, in Kazakhstan - by 5 positions. The ratings of Kyrgyzstan and Russia have increased by 23 and 1 positions, respectively.

Let us analyze the state of affairs with the goals of preserving the existing ecosystem (see Table 4). The classification of assessments of the level of achievement of goals is taken from the official terminology for the SDG Index.

Table 4. Achieving goals related to the preservation of the ecosystem of the EAEU member states

in line with the SDGs in 2020

\begin{tabular}{|l|l|l|l|l|l|}
\hline Country & $\begin{array}{l}\text { Goal No. 6: } \\
\text { Clean water and } \\
\text { sanitation }\end{array}$ & $\begin{array}{l}\text { Goal No. 7: } \\
\text { Affordable and } \\
\text { clean energy }\end{array}$ & $\begin{array}{l}\text { Goal No. 13: } \\
\text { Combating } \\
\text { climate change }\end{array}$ & $\begin{array}{l}\text { Goal No, 14: } \\
\text { Conservation of } \\
\text { marine } \\
\text { ecosystems }\end{array}$ & $\begin{array}{l}\text { Goal No. 15: } \\
\text { Conservation of } \\
\text { terrestrial } \\
\text { ecosystems }\end{array}$ \\
\hline Armenia & $\begin{array}{l}\text { Significant } \\
\text { challenges } \\
\text { remain }\end{array}$ & Achievements & Problems remain & No & $\begin{array}{l}\text { Significant } \\
\text { challenges } \\
\text { remain }\end{array}$ \\
\hline Belarus & Problems remain & Problems remain & $\begin{array}{l}\text { Significant } \\
\text { challenges } \\
\text { remain }\end{array}$ & No & Problems remain \\
\hline Kazakhstan & $\begin{array}{l}\text { Significant } \\
\text { challenges } \\
\text { remain }\end{array}$ & Problems remain & $\begin{array}{l}\text { Major challenges } \\
\text { remain }\end{array}$ & No & $\begin{array}{l}\text { Significant } \\
\text { challenges } \\
\text { remain }\end{array}$ \\
\hline Kyrgyzstan & $\begin{array}{l}\text { Significant } \\
\text { challenges }\end{array}$ & Problems remain & $\begin{array}{l}\text { Major challenges } \\
\text { remain }\end{array}$ & $\begin{array}{l}\text { No } \\
\text { challenges } \\
\text { remain }\end{array}$ \\
\hline Russia & Problems remain & Problems remain & $\begin{array}{l}\text { Major challenges } \\
\text { remain }\end{array}$ & $\begin{array}{l}\text { Significant } \\
\text { challenges } \\
\text { remain }\end{array}$ & $\begin{array}{l}\text { Significant } \\
\text { challenges } \\
\text { remain }\end{array}$ \\
\hline
\end{tabular}

\section{Source: UN data}

As can be seen from Table 4, only one country, Armenia, has achieved environmental goals in terms of goal No.7 "Affordable and Clean Energy", which is associated with the rapid development of renewable energy sources (RES), whose share in the country energy balance occupied $32.5 \%$ in 2020, and by 2026 it will be 50\%. Over the past 10 years, the volume of renewable energy in Armenia has grown 15 times. All other EAEU countries have significant problems to achieve goal No.7 "Affordable and Clean Energy". However, as can be seen from the table. 5, Armenia's SDG rating dropped by 8 positions from 2016 to 2020 , which is associated with problems with clean water and the preservation of terrestrial ecosystems. In addition, Armenia has problems in achieving other SDGs.

According to the goals: "Clean water and sanitation", "Fight against climate change" and "Preservation of terrestrial ecosystems" all Eurasian countries have significant problems. "Conservation of Marine Ecosystems" goal exists only for Russia, which still has significant difficulties in achieving it. Analyzing the achievement of the SDGs, the Bertelsmann Stiftung in its report on the achievement of the SDGs for East Asian countries, made a recommendation to better align economic development with environmental sustainability.

The existing geopolitical and economic situation makes it difficult for the EAEU member states to achieve the UN SDGs. But at the same time, the Eurasian member states of the Union had the greatest progress along the path of sustainable development and achievement of the UN SDGs in those areas of the economy that are involved in Eurasian integration and are regulated by supranational measures (Glazyev et al., 2018). 
The UN annual report dated July 6, 2021 notes that the COVID-19 pandemic has stalled the implementation of the Sustainable Development Goals, in particular SDG 3, target 3.3, which provides for ending the epidemics of AIDS, tuberculosis, malaria and tropical diseases by 2030. Tackling epidemics is also highlighted in SDG 6. A crisis in habitat or biodiversity increases the risk of new infectious diseases. This also affected the EAEU member states. Pandemic highlighted links between environmental, economic and social dimensions of sustainable development (Bobylev, 2020).

All member states of the Eurasian Economic Union have ratified the Paris Agreement (2015), which sets the goal of keeping the average temperature rise by the end of the 21 st century well below $2{ }^{\circ} \mathrm{C}$ above pre-industrial indicators, and limiting the temperature rise to $1.5^{\circ} \mathrm{C}$. Under the Paris Agreement, each EAEU member country has established a Nationally Determined Contribution (NDC) to reduce greenhouse gas emissions.

Table 5 presents data on the level of carbon dioxide emissions into the atmosphere in the EAEU member states in comparison with China, the USA and India.

As can be seen from Table 5, the first place in terms of CO2 emissions in 2019 was occupied by China, whose share in the total emissions of the planet was $32.48 \%$. The second place in CO2 emissions belongs to the USA - $14.38 \%$, the third - to India - 7.31\%, the fourth - to Russia - $5.05 \%$ of the global emissions.

Table 5. CO2 emissions into the atmosphere in the EAEU member states and the world in 2011-2019 (million tons)

\begin{tabular}{|l|l|l|l|l|l|l|}
\hline Countris & 2011 & 2015 & 2019 & $\begin{array}{l}\text { A place } \\
\text { in the } \\
\text { world } \\
2019\end{array}$ & $\begin{array}{l}\text { Change } \\
2015 / 2011 \\
(\%)\end{array}$ & $\begin{array}{l}\text { Change } \\
2019 / 2015 \\
(\%)\end{array}$ \\
\hline USA, China, India & \multicolumn{7}{l|}{} \\
\hline China & 10037 & 10671,3 & 11535,2 & 1 & +6 & +8 \\
\hline USA & 5438 & 5249 & 5107,3 & 2 & $-3,5$ & $-2,7$ \\
\hline India & 1858 & 2293 & 2597,4 & 3 & $+23,4$ & $+13,3$ \\
\hline EAEU member countries & 5,1 & 5,0 & 5,9 & 120 & -2 & +18 \\
\hline Armenia & 64,3 & 60,4 & 66,34 & 48 & $+6,1$ & $+9,8$ \\
\hline Belarus & 259,8 & 251,7 & 277,4 & 20 & $+3,1$ & $+10,2$ \\
\hline Kazakhstan & 7,8 & 10,6 & 11,9 & 94 & $+35,9$ & $+12,3$ \\
\hline Kyrgyzstan & 1818 & 1730,5 & 1792,0 & 4 & $+4,8$ & $+3,6$ \\
\hline Russia & 2155 & 2058,2 & 2153,54 & - & $-4,49$ & $+10,46$ \\
\hline EAEU &
\end{tabular}

Source: Knoema.World Data Atlas

The share of CO2 emissions from all EAEU member countries of the global indicator in 2019 was $6.06 \%$ (slightly less than India indicator). At the same time, the share of Russia in the total CO2 emissions of the EAEU countries amounted to $83.2 \%$, and together with Kazakhstan, this share is equal to $96.12 \%$. Environmental problems annually cause damage to Russia, reaching $15 \%$ of GDP, and in terms of energy efficiency, the Russian economy lags behind the advanced countries of the world by 2-3 times (Danilov-Danil'yan et al, 2020).

Average annual growth rates of CO2 emissions in Armenia, Belarus, Kazakhstan, Kyrgyzstan and Russia from 2011 to 2015 were negative and amounted to $4.49 \%$. Over the 5 years of the EAEU existence, from 2015 to 2019 , they grew by $10.46 \%$, which is higher than the growth rate of $\mathrm{CO} 2$ emissions over the same period in China $(+8 \%)$, but lower than in India (+13.3). At the same time, the United States reduced annual CO2 growth between 2011 and 2015 by $3.5 \%$ and from 2015 to 2019 by and $2.5 \%$ (see Table 5). This indicates that there are serious environmental problems within the EAEU and it is necessary to improve the efficiency of the agreed environmental policy (Ilyin and Ursul, 2019).

On July 14, 2021, the European Commission adopted the Climate Change Program, which provides for the introduction of a carbon border tax (CBT) on imported goods. This tax is part of the European Green Deal. From 2023, in the EU, importers will be required to report on the carbon footprint of imported products, and from 2026 - to pay CBT. In this case, the payment rate will be linked to EU Emissions Trading System (ETS) (Porfiryev et al., 2020 ).

The share of the European Union countries in the foreign trade turnover of the EAEU member states in 2020 was $36.8 \%$. The countries of the European Union are important trading partners for the EAEU member states. The EU occupies a large share in the exports of Eurasian countries. According to the estimates of the Eurasian Economic Commission (EEC), $20 \%$ of goods exported to the EU may fall under the influence of cross-border carbon regulation, and if carbon regulation is tightened in the long term, up to $80 \%$ of export products supplied from the EAEU to the European Union. According to the European Commission (EC), the EU countries can receive from $\$ 5$ billion to $\$ 14$ billion annually to the budget by levying a border tax on carbon emissions on imported goods.

The competitiveness of the EAEU member countries with resource economies and a large carbon footprint in manufactured products (especially in Russia and Kazakhstan) may decrease in the global market. According to the Ministry of Economic Development of the Russian Federation, for example, the potential losses from the introduction of a carbon tax for Russian companies could amount to $\$ 7.6$ billion per year. Currently, only Kazakhstan from the member 
countries of the Eurasian Economic Union has a greenhouse gas emissions trading system (Emissions Trading System) (Nesterenko et al, 2020).

On July 2, 2021, the President of the Russian Federation V.V. Putin signed the Federal Law "On limiting greenhouse gas emissions", which will create a system for managing greenhouse gas emissions, and the carbon footprint will become an important indicator of economic development. In Russia, the ETS (Emissions Trading System) has not yet been created, as in the UK, Norway, Switzerland and a number of other European countries, as in China or South Korea. The basic principles of carbon regulation are enshrined in the aforementioned Federal Law. In Russia, 25\% of CO2 emissions are absorbed by forests. At the same time, according to experts, without the introduction of drastic measures in 2022, absorption may decrease by $10 \%$. Carbon regulation in Russia will start working in 2022 . Russia, in accordance with the NDC (Nationally Determined Contribution), pledged to reduce greenhouse gas emissions by $70 \%$ by 2030 compared to 1990 levels. The country plans to achieve carbon neutrality by 2100 .

Armenia has set its NDC at 633 million tonnes of CO2 from 2015 to 2050 and has set the goal of achieving greenhouse gas neutrality by 2050. At the same time, the country plans to increase the level of these emissions from 11 million tons in 2020 to 15.5 million tons in 2030. This can be explained by the fact that after the collapse of the USSR, there was a powerful deindustrialization of the Armenian economy, especially in the manufacturing industry, which needs to be revived. And this will be steadily accompanied by an increase in greenhouse gas emissions.

Belarus in 2016 set the NDC goal - to reduce greenhouse gas emissions by 2030 by $28 \%$ from the 1990 level, and every 5 years the commitment will be revised to a more ambitious one. Belarus participates in the European EU for Climate Project, which is funded by the European Union and implemented by the United Nations Development Program (UNDP). The aim is to assist the Republic of Belarus in the implementation of the Paris Climate Agreement.

In Kazakhstan, back in 2013, the Emissions Trading System (ETS-KZ) was created, which sets a "carbon price" and regulates about $40 \%$ of internal $\mathrm{CO} 2$ emissions from 225 large enterprises of the electric power industry, mining and processing industry, district heating, which have CO2 emissions per year is more than 20 thousand tons. In December 2020, at a virtual climate summit, Kazakhstan pledged to reduce greenhouse gas emissions by $15 \%$ by 2030 compared to 1990, and set the goal of achieving carbon neutrality by 2060. Kazakhstan has partnered with the World Bank through the Market Readiness Partnership, which helped the country to create an electronic reporting platform for greenhouse gas emissions and to carry out activities to move towards carbon neutrality. The country has adopted the project "Updating the NDC in the Republic of Kazakhstan until 2030", which is aimed at strengthening the ETS and introducing a carbon tax. In the 4th five-year plan, as well as in the 5th and 6th National Five-Year Plans for 2022-2030, the distribution of quotas for greenhouse gas emissions is provided. However, despite the measures taken to decarbonize, $\mathrm{CO} 2 \mathrm{emissions}$ in the country are still growing (see Table 5).

Kyrgyzstan in 2020 pledged to reduce greenhouse gas emissions by $11.49-13.75 \%$ to 2030 (with international financial support - by $29.0 \%-30.9 \%$ ) and by $12.67-15.69 \%$ to 2050 year. The country is preparing a "National Position Paper on Climate Policy of the Kyrgyz Republic" within the framework of the project "Political Actions to Ensure Climate Security in Central Asia", which is also being implemented by UNDP in Tajikistan and Uzbekistan.

The environmental problems of transboundary states also affect the ecology of the EAEU countries. For example, the state of the environment in China undoubtedly affects a number of EAEU countries. On the one hand, the Agreement on the Interconnection of the EAEU and the Silk Road Economic Belt (SREB) was signed, on the other, Russia and China did not ratify the Convention on Environmental Impact Assessment in a Transboundary Context (Espoo Convention) (1991). In accordance with this Convention, the signatory countries, when implementing economic projects in transboundary regions, must carry out a strategic environmental impact assessment to assess their impact on the environment. In the Russian Federation, the ecological well-being of about 20 regions depends on transboundary factors (Burmatova, 2021). China and Russia have also not ratified the Aarhus Convention on Access to Information, Public Participation in Decision-Making and Access to Justice in Environmental Matters (1998). Other EAEU member states: Armenia, Belarus, Kyrgyzstan and Kazakhstan, have ratified both of the above conventions. At the same time, within the framework of the SREB, the Silk Road Ecological Investment Fund has been formed, designed to carry out measures to protect the environment and promote green energy (Yakovlev, 2020). Representatives of environmental movements from 11 countries of the world put forward in 2016 the international initiative "Green Silk Road". It is necessary to increase the efficiency of environmental interaction with countries of transboundary interaction. There is a need for state stimulation of environmental modernization processes in all EAEU member states (Greenberg and Pylin, 2020).

On June 17, 2021, at a meeting of the Scientific and Technical Council of the Eurasian Economic Union, it was proposed to endow the Eurasian Economic Commission with powers on the climate agenda in the EAEU, the issue of harmonizing measures to implement the Paris Agreement and unified regulation of the environmental management system within the Union was raised (Ryazantsev,2021).

\section{Conclusion}

The member countries of the Eurasian Economic Union have resource-oriented export-oriented economies that have a large anthropogenic impact on the environment. Analysis of environmental performance indicators (EPI, SEDA) from 
2010 to 2020 showed that in the EAEU there was a decrease in the efficiency of the rational use of ecosystems and natural resources, environmental problems are growing. The dynamics of the EAEU countries in terms of the UN sustainable development goals has been investigated; it was revealed that a number of EAEU countries had their SDG Index ratings downgraded from 2016 to 2020 . The state of affairs with the goals of preserving the existing ecosystem has deteriorated over the years in all 5 countries. The COVID-19 pandemic has slowed down the implementation of the SDGs in the countries of the Union.

The dynamics of the level of $\mathrm{CO} 2$ emissions into the atmosphere in the Union countries in comparison with China, the USA and India was revealed, which confirmed the unfavorable environmental situation in the EAEU, especially in Russia and Kazakhstan. The analysis of the planned policy of the EAEU member states to reduce greenhouse gas emissions under the Paris Agreement was carried out and the conclusion was made that the competitiveness of the EAEU member countries with resource economies and a large carbon footprint in manufactured products (especially in Russia and Kazakhstan) may decrease in the global market. Environmental cooperation of the EAEU states with cross-border Eurasian countries and, first of all, with China is important.

There is no uniform environmental legislation in the countries of the Eurasian Economic Union. Integration in the economic sphere should be complemented by integration in the field of environmental policy of the Eurasian countries, which requires the harmonization of environmental legislation and the adoption of environmental laws within the EAEU, especially regarding shared natural resources. The environmental factor hinders the progress of the EAEU countries along the path of sustainable development. it is necessary to state stimulation of the processes of ecological modernization in them. Active environmental cooperation of the Union states is a very important form of integration, contributing to progress along the path of sustainable development.

\section{Acknowledgments} 00674 .

The study was carried out with the grant support of the Russian Foundation for Basic Research, project № 20-010-

\section{References}

1. Abramov, V.L., Kodirov, F.A., Gibadullin, A.A., Nezamaikin, V.N., Borisov, O.I. \& Lapenkova N.V. (2020) Formation of Mechanisms for Ensuring the Sustainability of Industry. JOP Conference Series: Metrological Support of Innovative Technologies. Krasnoyarsk Science and Technology City Hall of the Russian Union of Scientific and Engineering Associations. Krasnoyarsk, Russia, 32025. https://doi.org/10.1088 / 1742-6596 / 1515/3/032025.

2. Bobylev, S.N. (2020). Environmental Consequences of Covid-19 on the Global and Russian Economics. Population and Economics, 2 (4), 43-48. https://doi.org/10.3897/popecon.4.e53279.

3. Borkova, E.A., Sopina, N.V., Gavrilyuk, E.S., Kuznetsov, N.V. \& Novikova, I.B. (2020). State Support for Green Investments and Market Green Financing in Renewable Energy Sources. Proceedings of the 35th International Business Information Management Association (IBIMA), 1-2 April 2020, Seville, Spain, 3808-3814. https://www.webofscience.com/wos/woscc/full-record/WOS:000661127404016

4. Burmatova, O.P. (2021). Environmental challenges in the region: analysis, ways to prevent risks and reduce threatsEconomy of the region, 1(17), 249-261. https://doi.org/10.17059/ekon.reg.2021-1-19.

5. Danilov-Danil'yan, V.I., Kattsov, V.M. \& Porfiriev, B.N. (2020). The Problem of Climate Change: the Field of Convergence and Interaction Between Natural Sciences and the Sociohumanities. Herald of the Russian Academy of Sciences, 10 (90), 577-587. https://doi.org/ 10.31857/S0321059620050053.

6. Dyatlov, Sergey and Selishcheva, Tamara (2020). Principles, Tools and Indicators for Sustainable Development// Proceedings of the 35th International Business Information Management Association Conference (IBIMA). 1-2 April 2020. Seville, Spain. Education Excellence and Innovation Management: A 2025 Vision to Sustain Economic Development during Global Challenges/Editor Khalid S. Soliman. Spain. International Business Information Management Association (IBIMA). 10, 7081-7995. https://www.webofscience.com/wos/woscc/fullrecord/WOS:000661127407051.

7. Fucks, R. (2016). Green Revolution: Eco-Friendly Growth, Moscow, 328.

8. Gibadullin, A.A., Pulyaeva, V.N., Kharitonova, E.N. \& Kharitonova, N.A. (2019). Convergence of the Russian Power Industry in a Period of Declining Reliability and Sustainability of the Industry. Journal of Physics: Conference Series. International Scientific Conference "Conference on Applied Physics, Information Technologies and Engineering - APITECH-2019. Krasnoyarsk Science and Technology City Hall of the Russian Union of Scientific and Engineering Associations; Polytechnical Institute of Siberian Federal University. 2019. C. 33034. https://doi.org/ 10.1088 / 1742-6596 / 1399/3/033034. 
9. Glazyev, S. Yu., Ajvazov, A. E. \& Belikov, V. A. (2018). The Future of the World Economy Is an Integrated World Economic Structure. Economy of Region, 14(1), 1-12. https://doi.org/10.17059/2018-1-1.

10. Greenberg, R.S., \& Pylin, A.G. (2020). Eurasian Economic Union. Main development trends against the backdrop of global uncertainty. Economy of the region, 2 (16), 340-351. https://doi.org/10.17059/2020-2-1.

11. Greenberg, R.S., Belozerov S.A., Sokolovskaya E.V. (2021). Assessment of the effectiveness of economic sanctions. Systematic analysis capabilities. Economy of the Region, 2 (17),354-374. https://doi.org/10.17059/ ekon.reg.20212-1 1

12. Ilyin, I.V. \& Ursul, A.D. (2019). Towards a Sustainable Global World. Journal of Chinese Philosophy, 3-4(46), 224235. https://doi.org/ 10.1111/1540-6253.12387.

13. Meadows, D. H., Randers, J. and Meadows D. L. (2014). Growth limits: 30 years later [Electronic resource] /; per. from English E. S. Oganesyan; ed. NP Tarasova. - 2nd ed. (email). -Electron. text data. (1 pdf file: 361 p.). -

M.: BINOM. Knowledge Laboratory, System. Requirements: Creation: Adobe Reader XI; screen 10 ". ISBN 978-5-9963$2577-1$

14. Nesterenko, N., Pakhomova, N. \& Richter, K.K. (2020). Sustainable development of organic agriculture: strategies of Russia and its regions in context of the application of digital economy technologies. St Petersburg University Journal of Economic Studies, 2 (36), 217-242. https://doi.org/ 10.21638/spbu05.2020.203.

15. Nordhaus, W. (2018). Evolution of modeling of the economics of global warming: changes in the DICE model, 1992-2017. Climatic Change, 148, 623-640. https://doi.org/10.1007/s10584-018-2218-y.

16. Porfiriev, B.N., B.N., Shirov, A.A. \& Kolpakov, A.Yu. (2020). Low-carbon development strategy: prospects for the Russian economy. World economy and international relations, 9 (6), 15-25. https://doi.org/ 10.20542/0131-22272020-64-9-15-25

17. Ryazantsev, S.V., Rostovskaya, T.K. \& Zolotareva, O.A. (2021). A system for measuring the sustainability of socioeconomic development of the EAEU countries. Economy of the region, 3(17), 971-986. https://doi.org/10.17059/ ekon.reg.2021-3-18.

18. Selishcheva, T., Dronov, R., Ananyev, A. \& Nuyanzin, V. (2019). Sustainable development of the Russian crossborder regions in Eurasian integration. International Business Information Management Association (IBIMA). Proceedings of the 34th International Business Information Management Association Conference (IBIMA). Editor Khalid S. Soliman, 9937-9946. https:/www.webofscience.com/wos/woscc/fullrecord/WOS:000561117204013.

19. Semyachkov, A.I., Gao, Zh \& Atamanova, E.A. (2021). Management of the natural resource potential of the region based on the variability of environmental and economic indicators. Economy of the region, 2(17), 520-537. https://doi.org/10.17059/ekon.reg.2021-2-12

20. Tol, Richard S J. (2019). Climate Economics (2nd Edition). Economic Analysis of Climate, Climate Change and Climate Policy, Second Edition by Tol, Richard S J. Published by Edward Elgar Pub, 256.

21. Yakovlev, I. A., Kabir, L. S., Nikulina, S. I. \& Rakov, I. D. (2020).Transformation of the national policy of resourcebased countries under the influence of the global agenda for sustainable development. Economy of the region. 3(16), 859-870. https://doi.org/10.17059/ekon.reg.2020-3-. 